\title{
At the Intersections: International and Multicultural Higher Education
}

\author{
Lauren K. Chow \\ Lesley University, United States \\ Email: 1chow@lesley.edu \\ Address: Lesley University, Massachusetts, USA
}

\section{Introduction}

International education and multicultural education in the United States appear to have similar goals: educating students to appreciate differences across groups of people. However, further examination reveals that these two spheres not only frequently fail to overlap, but also sometimes compete on both practical and ideological levels (Olson, Evans, and Shoenberg 2007). The potential for partnership is great between international and multicultural education in higher education contexts due to shared goals. However, tension and gaps going back as far as the 1990s (Bennett and Bennett 1994; Cornwell and Stoddard 1999; Noronha 1992) and have diminished their efficacy in supporting the students and communities they purport to serve.

The purpose of this study was to illuminate how the "similar goals and dueling agendas" (Bell 2013, 1) of US international and multicultural higher education currently operate. International education refers to the internationalization of a campus, including student mobility, curriculum, and co-curricular activities. Multicultural education refers to concerns of diversity, equity, and inclusion, and includes content integration, the process of knowledge construction, and prejudice reduction. The question guiding this study was: How do international and multicultural offices frame their work, and what does this language tell us about the intersections or divergences in their work to create an inclusive campus environment?

\section{Literature Review}

Collaborative intra-organizational partnerships have been studied as an effective strategy to combat external pressures (Kezar 2006). Much literature explored why tensions between international and multicultural education may exist and potential avenues for collaboration on a broad, theoretical level (Charles, Longerbeam, and Miller 2013; Olson, Evans, and Shoenberg 2007). Lee (2018) argued that "it is critical that campuses shift from a deficit model to one that focuses on its strengths and assets" (70). However, there lies a fine balance between shifting to an asset model and glossing over inequalities, playing into a dynamic wherein "multicultural educators accuse international educators of ignoring pressing social problems at home and avoiding difficult questions" (Olson, Evans, and Shoenberg 2007, 23). Aside from a longitudinal project by the American Council on Education (2013) and a white paper by Bell, Donaghue, and Gordon (2018), little research has systematically examined the practical realities of these intersections at higher education institutions. The higher education landscape has changed dramatically in the past decade with technological developments, soaring tuition costs amidst tightened budgets, and a contentious global political climate (Grawe 2018; Stein 2017), which has rendered older research less relevant.

\section{Framework}


This research was grounded by Kretzmann and McKnight's (1996) assets-based community development theory. This approach was created in response to a needs-based or deficit-based model of community development that had been widely practiced until that point. This model has since been adapted to higher education contexts (Chávez and Longerbeam 2016; Lopez and Louis 2009). Rather than assessing the needs of a community by focusing on what is missing and seeking resources from outside sources, Kretzmann and McKnight's (1996) assets-based community development theory methodology instead suggested empowerment through leveraging existing strengths within a community.

\section{Methods}

I employed content analysis methodology (Stemler 2001) to examine the language used in the webpages for international and multicultural offices of ten colleges/universities. The institutions selected were all four-year degreegranting, predominantly white, and located within the state of Massachusetts. They represented a variety of institutional types, size, and location for maximum variation sampling (Glesne 2016, 51) and each were assigned pseudonyms.

In March 2019, I gathered data related to the institutions' mission and values, and from offices that could be categorized as "international" or "multicultural." Analysis included two rounds of thematic coding followed by a collapsing into a list of broader themes (Glesne 2016, 184). Asset themes were defined by language that framed an office's work through a strengths-based lens that focused on positive aspects; deficit themes were defined by language that framed work through a needs-based lens that emphasized problems to be solved.

\section{Findings}

Ten preliminary themes emerged from my content analysis of the multicultural and international office websites. Six themes fell under an asset category: Adding perspectives to a campus community; Marketable skills and competitive advantages; Personal growth, Student success and retention; Opportunity, access, and representation; and Prestige. Four themes fell under a deficit category: Access, opportunity, and representation; Responsibility and compliance; Safety and protection; and Unwelcoming environment. The "asset" themes were reflected more in international office websites, and the "deficit" themes were reflected overwhelmingly more in multicultural office websites.

\section{Discussion and Implications}

The association of multicultural education with "deficit" and international education with "asset" aligns with Olson, Evans, and Schoenberg's (2007) discussion of asset and deficit models when bridging the two areas. These authors highlighted the contrast in international education's association with "fun" and "prestige" with the view of multicultural education as "necessary... but lacking in glamour" (30). This dichotomy surfaced in many ways throughout the six asset-based themes that were mostly found in international office websites and the four deficit-based themes that were overwhelmingly found in multicultural office websites.

Data analysis also revealed four shared themes in how both office types framed their work. Adding perspectives; Opportunity, access, and representation; and Prestige were asset-based themes reflected by both office types; Safety and protection was the common theme from a deficit lens. Centering mutual learning outcomes around these themes could provide opportunities for collaboration and further dialogue. By understanding more about how these two areas described their work, the scholarly conversation about and between them can move towards creating a dialogue 
between the two (Landorf 2013, 102). Partnerships can be mutually beneficial for serving their communities in the current higher education landscape (Kezar 2006).

Future research might examine how the boundaries of "international" and "multicultural" offices are delineated: a challenge that emerged during data collection when different institutions defined these areas differently. Furthermore, this study employed content analysis to examine language used on public websites; however, many institutional activities are not reflected on websites. I am currently analyzing data from interviews I conducted with administrators in multicultural and international offices at the same institutions highlighted in this study, which will lead a more comprehensive analysis and further insights when the two sets of data are combined.

\section{References}

American Council on Education. 2013. "At Home in the World: Educating for Global Connections and Local Commitments." At Home in the World. American Council on Education. http://www.acenet.edu/aboutace/special-initiatives/Pages/At-Home-in-the-World.aspx.

Bell, Kathrina A. 2013. "Similar Goals and Dueling Agendas: Perceptions of Campus Internationalization and Equity Policy.” EdD diss., San Francisco State University.

Bell, Kathrina, Jennifer Donaghue, \& Andrew Gordon. 2018. Collaborative Leadership: Advancing Diversity, Equity, and Comprehensive Internationalization in Higher Education. Berkeley, CA: Diversity Abroad Network. https://cdn.ymaws.com/www.diversitynetwork.org/resource/resmgr/Advancing_Diversity,_Equity,.pdf.

Bennett, Janet M., \& Milton J. Bennett. 1994. "Multiculturalism and International Education: Domestic and International Differences." In Learning Across Cultures, edited by Gary Althen, 145-165. Washington, DC: National Association of International Educators.

Chávez, Alicia \& Susan Longerbeam. 2016. Teaching Across Cultural Strengths: A Guide to Balancing Integrated and Individuated Cultural Frameworks in College Teaching. Sterling, VA: Stylus Publishing.

Charles, Harvey, Susan Longerbeam, \& Angela Miller. 2013. "Putting Old Tensions to Rest: Integrating Multicultural Education and Global Learning to Advance Student Development.” Journal of College and Character 14(1): 4756.

Cornwell, Grant H. \& Eve W. Stoddard. 1999. Globalizing Knowledge: Connecting International and Intercultural Studies. Washington, DC: Association of American Colleges and Universities.

Cortés, Carlos E. 1998. "Global Education and Multicultural Education: Toward a 21st Century Intersection." In Intersections: A Professional Development Project in Multicultural Education and Global Education, Asian and American Studies, edited by Leslie Swartz, Linda Warner, and David Grossman, 114-133. Boston: The Children's Museum.

Glesne, Corinne. 2016. Becoming Qualitative Researchers: An Introduction (5th Edition). Pearson. ISBN-13: 9780133859393

Grawe, Nathan. 2018. Demographics and the Demand for Higher Education. Baltimore, MD: Johns Hopkins University Press.

Kezar, Adrianna. 2006. "Redesigning for Collaboration in Learning Initiatives: An Examination of Four Highly Collaborative Campuses." The Journal of Higher Education 77(5): 804-838.

Kretzmann, John \& John P. McKnight. 1996. Assets-Based Community Development. National Civic Review 85(4): 23-29.

Landorf, Hillary. 2013. "Using the Dialectic of Social Justice to Enliven the Dialogue Between Global Education and Multicultural Education.” Journal of International Social Studies 3(2): 99-105.

Lopez, Shane J. \& Michelle C. Louis. 2009. "The Principles of Strengths-Based Education.” Journal of College and 
Character 10(4): 1-8.

Lee, Donna. 2018. "Closing the Gap and Exploring the Intersections Between Internationalization and Multiculturalism.” New Directions for Student Leadership (160): 63-73.

Noronha, June. 1992. "International and Multicultural Education: Unrelated Adversaries or Successful Partners?" New Directions for Teaching and Learning 52: 53-59.

Olson, Christa L., Rhodri Evans, \& Robert F. Shoenberg. 2007. At Home in the World: Bridging the Gap Between Internationalization and Multicultural Education. Washington, DC: American Council on Education.

Stein, Sharon. 2017. "Internationalization for an Uncertain Future: Tensions, Paradoxes, and Possibilities." The Review of Higher Education 41(1): 3-32. doi:10.1353/rhe.2017.0031.

Stemler, Steve. 2001. “An Overview of Content Analysis.” Practical Assessment, Research and Evaluation 7(17): 1-6. 